\title{
Inventory of glaciers in isla Riesco, Patagonia, Chile, based on aerial photography and satellite imagery
}

\author{
Gino Casassa, ${ }^{1,2}$ Katrine Smith, ${ }^{1,3}$ Andrés Rivera, ${ }^{4,2}$ José Araos, ${ }^{4}$ Michael Sahnirch, \\ Christoph SGhneider ${ }^{5}$ \\ ${ }^{1}$ Instituto de la Patagonia, Universidad de Magallanes, Av. Bulnes 01855, Punta Arenas, Chile \\ ${ }^{2}$ Centro de Estudios Científicos, Av. Arturo Prat 514, Valdivia, Chile \\ ${ }^{3}$ Environment and Resources, Technical University of Denmark, Kemitorvet, DK-2800 Lyngby, Denmark \\ ${ }^{4}$ Departamento de Geografía, Universidad de Chile, Av. Marcoleta 250, Santiago, Chile \\ ${ }^{5}$ Department of Physical Geography, University of Freiburg, Werderring 4, D-79085 Freiburg, Germany
}

\begin{abstract}
A glacier inventory for península Córdova, isla Riesco, Chilean Patagonia $\left(53^{\circ} 14^{\prime} \mathrm{S}, 73^{\circ} 00^{\prime} \mathrm{W}\right)$, has been compiled based on stereoscopic interpretation of aerial photographs of March and December 1984 and 1:100 000 topographic maps. Three small icefields comprising 33 glacier outlets, in addition to 12 small separate glaciers, have been identified, with a total area of $57 \mathrm{~km}^{2}$. Glaciers are located on mountain peaks with a maximum altitude of $1183 \mathrm{~m}$ and a lowermost elevation of $100 \mathrm{~m}$. All glaciers terminate on land, except for three glaciers calving into small fresh-water lakes. A Landsat Thematic Mapper (TM) image of 6 October 1986 has been rectified and analyzed using a supervised classification to estimate snow- and glacier-covered surfaces. Glacier-area data derived from satellite-image analyses have been adjusted at península Córdova using photo-interpreted data, and extrapolated to estimate a glacier area of $215 \pm 40 \mathrm{~km}^{2}$ for all of isla Riesco. The presence of trimlines and moraines beyond the present position of the glaciers indicates a generalized retreat from a maximum neoglacial position at península Córdova, most probably as a result of regional warming and precipitation decrease observed during the last century.
\end{abstract}

\section{INTRODUCTION}

The glacier inventory of Chile covers the Andean region from Arica $\left(18^{\circ} \mathrm{S}\right)$ in the north to the lake district $\left(41^{\circ} \mathrm{S}\right)$ in the south, including 1675 individual glaciers with a total area of $6606 \mathrm{~km}^{2}$ (Casassa, 1995; Rivera and others, 2000). These glacier inventories have been compiled largely by the Dirección General de Aguas (DGA; National Water Cadastre of Chile). The inventories and the study of glacier variations are especially important in basins close to populated areas in central-south Chile for estimating water resources and predicting future availability. This information is also important for studying climatic changes and for basic glaciological research.

In Patagonia, south of $41^{\circ} \mathrm{S}$, detailed glacier inventories and variations have been compiled only for Hielo Patagónico Norte and Sur (HPN and HPS; northern and southern Patagonia icefields), which include a total glacierized area of $17200 \mathrm{~km}^{2}$ and are by far the largest ice bodies in South America (Aniya, 1988; Aniya and others, 1996, 1997). HPN lies entirely in Chile, while approximately $81-92 \%$ of the area of HPS lies in Chile.

Two smaller icefields located south of HPS in Patagonia are currently being studied by multidisciplinary teams: Gran Campo Nevado in the southern part of península Muñoz Gamero (Kilian and others, 2000), with an approximate area of $200 \mathrm{~km}^{2}$; and isla Santa Inés to the south of the Strait of Magellan (personal communication from K. Bennet and V. Pojhola, 2001), with an estimated area of $100 \mathrm{~km}^{2}$. In Tierra del Fuego, recent variations of a few outlet glaciers of Cordillera Darwin (area approximately $2000 \mathrm{~km}^{2}$ ) have been determined (Holmlund and Fuenzalida, 1995). Glaciological measurements are being performed by C. Porter (personal communication, 2001) at a few outlet glaciers of Cordillera Darwin and the small ice cap of isla Hoste located south of the Beagle Channel, with an estimated area of $150 \mathrm{~km}^{2}$ (Casassa, 1995).

Large glacierized areas in southernmost Chile are virtually unstudied, with neither a glacier inventory nor an assessment of ice variations. The total uninventoried glacier area in Chile between $41^{\circ}$ and $55^{\circ} \mathrm{S}$ is estimated as $5200 \mathrm{~km}^{2}$ (Rivera and others, 2002). This paper describes the first glacier inventory for península Córdova, isla Riesco, based on aerial photographs. The inventory is extended to all of isla Riesco using a Landsat TM image and a simple lineal algorithm to correct for enhanced snow cover at the time of image acquisition.

\section{SITE DESGRIPTION}

Isla Riesco is a large island oriented approximately east-west, stretching from $52^{\circ} 40^{\prime}$ to $53^{\circ} 30^{\prime} \mathrm{S}$ and $73^{\circ} 30^{\prime}$ to $71^{\circ} 20^{\prime} \mathrm{W}$, about $130 \mathrm{~km}$ long and $50 \mathrm{~km}$ wide (Fig. 1). It is bounded to the north by Skyring sound, to the south by Otway sound, to the east by Fitz Roy channel, to the west by Gajardo channel, to the southwest by the Strait of Magellan and to the southeast by Jerónimo channel. Large Pleistocene glaciers occupied each of these waterways during the Last Glacial Maximum (Clapperton, 1993). Península Córdova is located at the southwestern end of isla Riesco, along the northern flank of the Strait of Magellan (Fig. 1). 


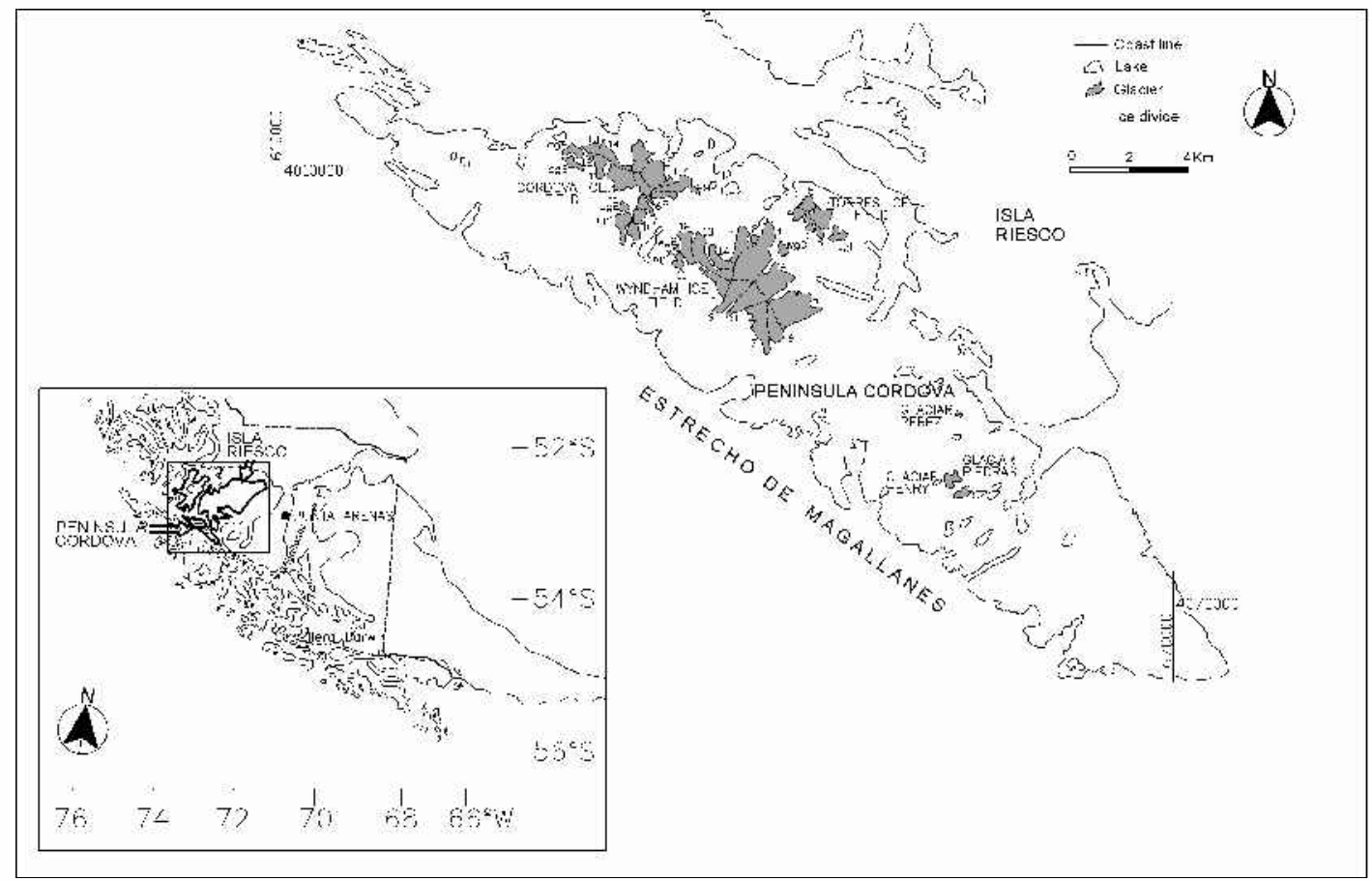

Fig. 1. Glaciers of peninsula Córdova, isla Riesco. Numbers and names correspond to the list in Table 1. Gridlines are expressed as Universal Transverse Mercator (UTM) coordinates. The inset shows the coastline of isla Riesco drawn with a thick line, where Peninsula Córdova appears on the lower left of the island. G is Gran Campo Nevado icefield, located on peninsula Muñoz Gamero.

The eastern part of the island is relatively flat and has moderate precipitation ( $<1000 \mathrm{~mm} \mathrm{a}^{-1}$; DGA, 1987) because it is located leeward of the Andes mountains. A few farms exist in this part of the island, mainly involved in cattle raising. The island has two gravel roads, each with a maximum length of about $50 \mathrm{~km}$, located along the shores of Skyring and Otway sounds. The western part of isla Riesco is located within the main belt of the Andean cordillera, with high precipitation rates $\left(>1000 \mathrm{~mm} \mathrm{a}^{-1}\right)$ driven by the strong westerly circulation. In this western sector, which is virtually uninhabited, the highest mountain peaks have an elevation of $1830 \mathrm{~m}$, including several small ice caps and mountain glaciers.

Sixty kilometres northwest of península Córdova lies Gran Campo Nevado, an ice cap of about $200 \mathrm{~km}^{2}$ (Casassa and others, 1998), which is presently being studied by a multidisciplinary German group (Kilian and others, 2000). Preliminary meteorological measurements show an annual precipitation of about $9 \mathrm{~m} \mathrm{a}^{-1}$ at canal Gajardo on the coast (personal communication from C. Schneider, 2001), which is probably also representative for the westernmost part of isla Riesco.

\section{METHODS AND DATA}

\section{Aerial photographs}

Vertical aerial photographs for península Córdova of March and December 1984 provide complete coverage during a period with relatively small snow accumulation. These photographs were acquired by Servicio Aerofotogramétrico of the Chilean Air Force with a $23 \times 23 \mathrm{~cm}$ format and a nominal scale of 1:60 000. The only other aerial photographs available for the area are the Trimetrogon vertical and oblique photographs acquired by the U.S. Air Force in 1944/45. Glacier boundaries, which generally appear quite distinct on the 1984 photographs, were plotted stereoscopically. Glacier margins were then drawn on 1:100000 maps of Instituto Geográfico Militar (IGM) sheets "Golfo Xaultegua" and "Estuario Wick- ham", using a monoscopic Zoom Transfer Scope of Bausch and Lomb. Three icefields and 12 small glaciers were detected on península Córdova (Fig. 1). For the icefields, individual catchment areas were identified for each glacier tongue, based on estimated ice divides according to the 1:100000 IGM maps.

The glacier margins and ice divides for península Córdova were digitized and imported as vector files to AutoCAD digital cartographic software. Polygons were defined semi-automatically using a topological scheme, calculating areas, lengths and mean glacier coordinates digitally. Glacier aspect, elevations and relief were estimated directly on the $1: 100000$ maps.

\section{Satellite imagery}

One Landsat TM image acquired on 6 October 1986 was available for isla Riesco (Fig. 2). The image has a nominal pixel resolution of $28.5 \mathrm{~m}$, and is almost entirely cloud-free, except for a small section southeast of península Córdova, near Jerónimo channel. Snow cover is unfortunately very extensive in the image, due to the early-spring acquisition period, making it difficult to distinguish glaciers from snow cover.

The image was geometrically rectified using a secondorder polynomial based on 38 points identified from the 1:100 000 maps, evenly distributed along isla Riesco. The mean registration error is 1.3 pixels $(36 \mathrm{~m})$, although maximum errors as large as 3 pixels $(86 \mathrm{~m})$ were detected at some locations relatively far from control points.

A supervised maximum-likelihood classification according to Engman and Gurney (1991) was carried out for isla Riesco for the classes sea water, shadow, clouds, glacier, snow and inland lake using Erdas Imagine 8.4 image-processing software. This semi-automatic technique did not perform adequately because glacier and snow were not clearly distinguished in the image. Instead, an on-screen digitizing of polygons of glaciated areas was carried out using a combination of bands 4, 5 and 7 which provided a satisfactory visual- 


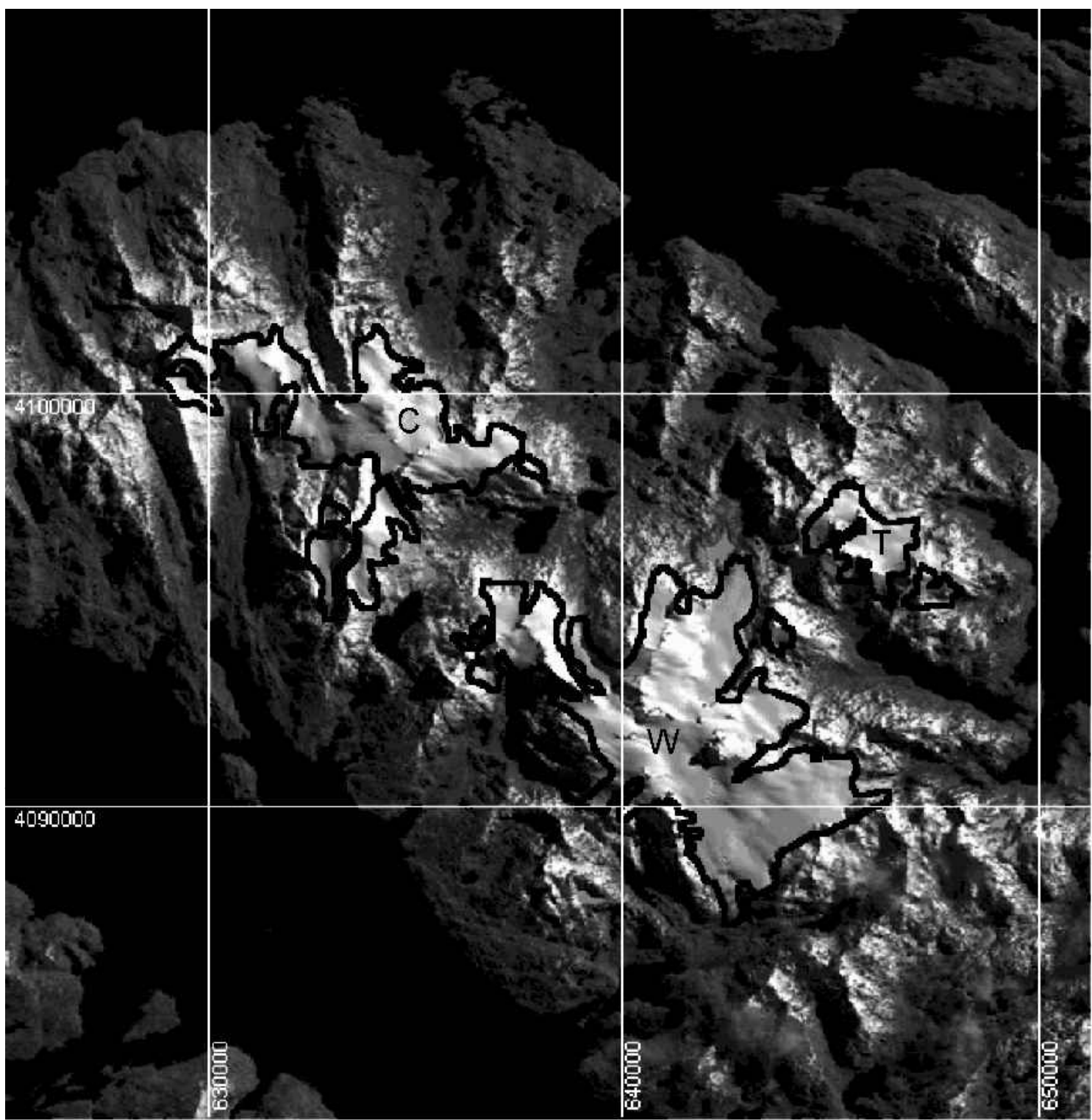

Fig. 2. Band 4 data (near-infrared) of a Landsat TMimage of Córdova icefield ( $C$ ),Wyndham icefield ( W) and Torres icefield (T) at peninsula Córdova, acquired on 6 October 1986. The thick black line shows the glacier perimeter interpreted from the aerial photographs. Glaciers appear larger in the image due to extensive snow cover at the time of image acquisition. Gridlines correspond to UTM coordinates.

ization. Combinations such as Landsat TM band 4/band 5 (near-infrared), which are typically used to distinguish snow from glacier ice (Engman and Gurney, 1991), did not perform adequately either, which is not surprising considering that probably fresh snow covered all of the glacier and some of the rock area at the time of image acquisition.

By using the on-screen digitizing scheme in combination with the unsupervised classification, an improved glacier area estimate was obtained for isla Riesco. Glacier areas were calculated digitally on the image using Idrisi 32 image-processing software, and are shown in Figure 3.

\section{GLACIER INVENTORY}

\section{Inventory of península Córdova derived from aerial photographs}

Three small icefields were identified at península Córdova from the aerial photographs: Córdova, Wyndham and Torres icefields (Fig. 1), with an area of $15.4,32.0$ and $3.8 \mathrm{~km}^{2}$, respectively. These icefields can be divided into 33 smaller catchment areas, each corresponding to a different glacier tongue that could be identified on the photographs. In addition, 12 separate small glaciers were found, with a total area of $5.6 \mathrm{~km}^{2}$. Considering both icefields and glaciers, the glacierized area for península Córdova is $56.8 \mathrm{~km}^{2}$.

The glacier inventory is shown in Table 1 , including mean latitude, longitude, length, area, aspect, nature of terminus, elevation and relief. Only three glaciers calve into small fresh-water lakes, the rest terminate on land, and none of the glaciers reaches sea level. No predominant glacier aspect can be found, and glaciers radiate in all directions. Accumulation and ablation areas could not be identified, because the local equilibrium-line altitude (ELA) is unknown (see next section).

The maximum elevation of península Córdova is $1183 \mathrm{~m}$ at Mount Wyndham, the highest point of Wyndham icefield, whereas the minimum elevation of glaciers on the peninsula is $100 \mathrm{~m}$, corresponding to the elevation of the proglacial lake of glacier 7 of Wyndham icefield. The second lowest glacier-front elevation is $300 \mathrm{~m}$. The mean highest elevation for all glaciers is $867 \mathrm{~m}$, while the mean elevation of the glacier fronts is $497 \mathrm{~m}$, yielding an overall average elevation of $682 \mathrm{~m}$ for the 


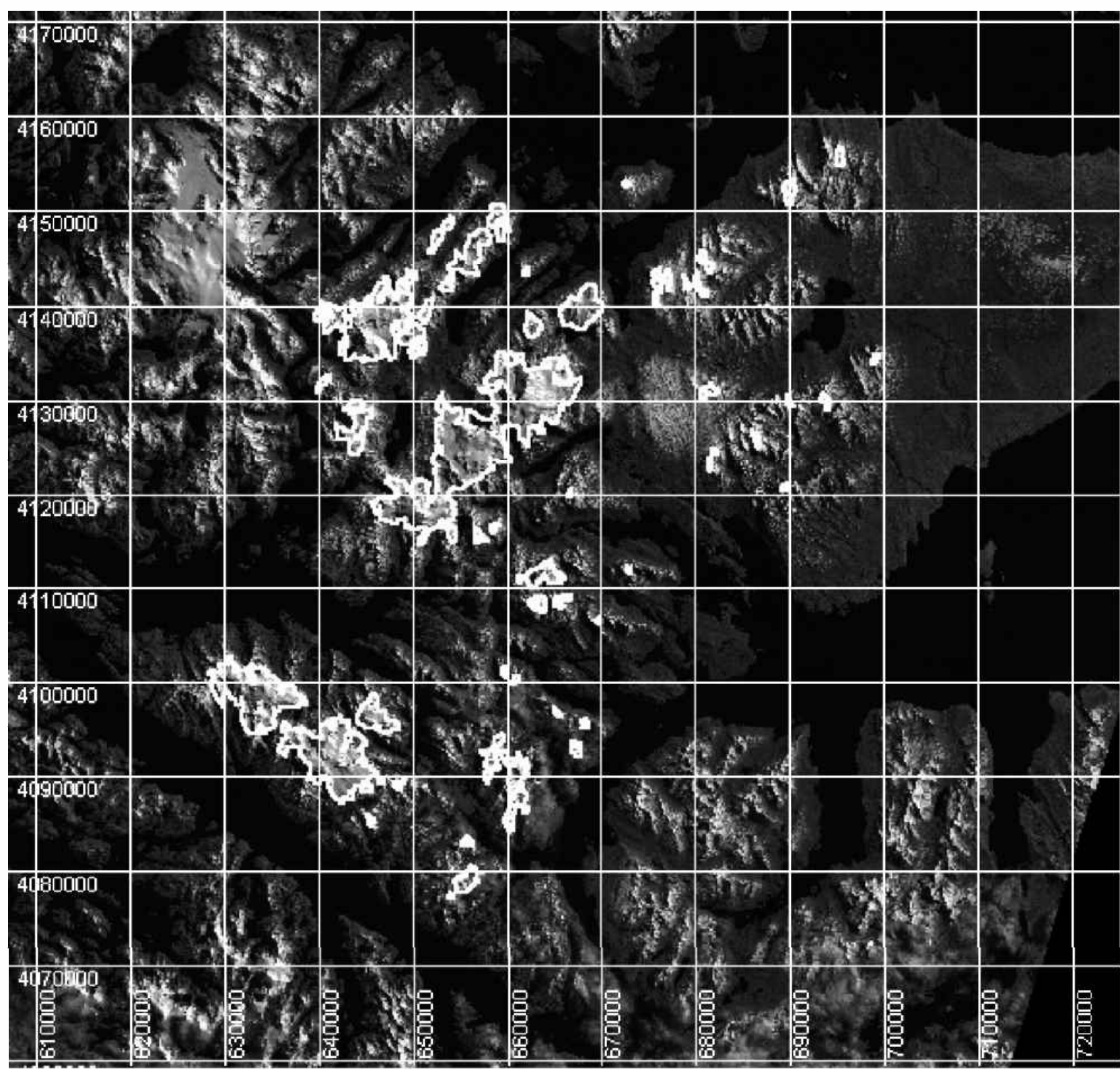

Fig. 3. Band 4 data (near-infrared) of the 6 October 1986 Landsat TM image for the central-western part of isla Riesco. The thick white lines show the glacier perimeter interpreted using a supervised classification as described in the text. Gridlines correspond to UTM coordinates.

glaciers. Maximum elevations for some glaciers such as CG3 and CG5 (Table 1; Fig. 1) are probably underestimated because of the low resolution of the 1:100 000 scale maps.

The above information indicates that glaciers at península Riesco are clearly confined to the mountain slopes, with small accumulation areas and with ablation areas that do not extend much beyond the mountain slopes. The only exception is glacier 7 of Wyndham icefield, which has a higher and larger accumulation area, with ice draining down to an elevation of $100 \mathrm{~m}$ in the ablation area.

\section{Inventory of isla Riesco derived from the Landsat} image

The Landsat image can be used to assess the glacier area for the rest of isla Riesco. This is done in the following way. Firstly, we can compare the glacier areas obtained for península Córdova by aerial-photograph interpretation, calculated as $56.8 \mathrm{~km}^{2}$, and by Landsat image analysis, which results in $98.7 \mathrm{~km}^{2}$. The areal overestimation of $74 \%$ using the Landsat image is clearly a consequence of interpreting seasonal snow present at the time of acquisition (early spring) as glacier ice. Assuming that the rest of isla Riesco has a similar snow cover at the time of image acquisition, we could simply estimate the glacier area from the analysis of the Landsat imagery, and reduce this area by the reciprocal of the overestimation factor (i.e. 1.74) calculated for península Córdova, that is $57 \%$.

A more accurate procedure to assess glacier coverage from the Landsat image was found by comparing the area of individual ice bodies estimated from the Landsat image with the area derived from the aerial photographs at península Córdova (Table 2; Fig. 4). The ratio $(R)$ of the glacier area obtained by aerial photographs $\left(A_{\mathrm{P}}\right)$ and the area obtained by the Landsat image $\left(A_{\mathrm{L}}\right)$, calculated as the ratio $R=A_{\mathrm{P}} A_{\mathrm{L}}^{-1}$, was found to be linearly dependent on $A_{\mathrm{L}}$, as a first-order approximation, for $A_{\mathrm{L}}$ values of $1-47 \mathrm{~km}^{2}$. This means that the glacier-area overestimation associated with the Landsat image interpretation is larger for smaller glacier areas. The largest ice mass in península Córdova is the Wyndham glaciers, with $A_{\mathrm{L}}=47 \mathrm{~km}^{2}$ and $R=0.63$. For areas exceeding $47 \mathrm{~km}^{2}$ a constant ratio of 0.63 was adopted 
Table 1. Glacier inventory for peninsula Córdova. Calving column: $\mathcal{N}$, non-calving glaciers; L, glaciers calving into freshwater lakes Meanlocation $\begin{gathered}\text { Length of Area Aspect Cal-Max.Min. Relief } \\ \text { glacier }\end{gathered}$
ving elev. elev. $\mathrm{km} \quad \mathrm{km}^{2}$

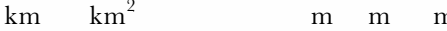

Córdova icefield

CIF $1 \quad 53^{\circ} 13^{\prime} \mathrm{S}, 72^{\circ} 59^{\prime} \mathrm{W}$

CIF $2 \quad 53^{\circ} 14^{\prime} \mathrm{S}, 72^{\circ} 58^{\prime} \mathrm{W}$

CIF $3 \quad 53^{\circ} 14^{\prime} \mathrm{S}, 72^{\circ} 57^{\prime} \mathrm{W}$

CIF $4 \quad 53^{\circ} 14^{\prime} \mathrm{S}, 72^{\circ} 57^{\prime} \mathrm{W}$

CIF $5 \quad 53^{\circ} 15^{\prime} \mathrm{S}, 72^{\circ} 58^{\prime} \mathrm{W}$

CIF $6 \quad 53^{\circ} 14^{\prime} \mathrm{S}, 72^{\circ} 58^{\prime} \mathrm{W}$

CIF $7 \quad 53^{\circ} 15^{\prime} \mathrm{S}, 72^{\circ} 59^{\prime} \mathrm{W}$

CIF $8 \quad 53^{\circ} 15^{\prime} \mathrm{S}, 72^{\circ} 59^{\prime} \mathrm{W}$

CIF $9 \quad 53^{\circ} 16^{\prime} \mathrm{S}, 72^{\circ} 59^{\prime} \mathrm{W}$

CIF $10 \quad 53^{\circ} 14^{\prime} \mathrm{S}, 73^{\circ} 00^{\prime} \mathrm{W}$

CIF $11 \quad 53^{\circ} 13^{\prime} \mathrm{S}, 73^{\circ} 01^{\prime} \mathrm{W}$

CIF $12 \quad 53^{\circ} 13^{\prime} \mathrm{S}, 73^{\circ} 02^{\prime} \mathrm{W}$

CIF $1353^{\circ} 13^{\prime} \mathrm{S}, 73^{\circ} 02^{\prime} \mathrm{W}$

CIF $14 \quad 53^{\circ} 13^{\prime} \mathrm{S}, 73^{\circ} 01^{\prime} \mathrm{W}$

Córdova glaciers

CG1 $53^{\circ} 16^{\prime} \mathrm{S}, 73^{\circ} 00^{\prime} \mathrm{W}$

CG2 $53^{\circ} 15^{\prime} \mathrm{S}, 73^{\circ} 00^{\prime} \mathrm{W}$

CG3 $53^{\circ} 13^{\prime} \mathrm{S}, 73^{\circ} 03^{\prime} \mathrm{W}$

CG4 $53^{\circ} 13^{\prime} \mathrm{S}, 73^{\circ} 03^{\prime} \mathrm{W}$

CG5 $53^{\circ} 15^{\prime} \mathrm{S}, 72^{\circ} 56^{\prime} \mathrm{W}$

Wyndham icefield

WIF $1 \quad 53^{\circ} 17^{\prime} \mathrm{S}, 72^{\circ} 53^{\prime} \mathrm{W}$

WIF $253^{\circ} 16^{\prime} \mathrm{S}, 72^{\circ} 52^{\prime} \mathrm{W}$

WIF $3 \quad 53^{\circ} 17^{\prime} \mathrm{S}, 72^{\circ} 52^{\prime} \mathrm{W}$

WIF $453^{\circ} 17^{\prime} \mathrm{S}, 72^{\circ} 51^{\prime} \mathrm{W}$

WIF $5 \quad 53^{\circ} 18^{\prime} \mathrm{S}, 72^{\circ} 50^{\prime} \mathrm{W}$

WIF $6 \quad 53^{\circ} 19^{\prime} \mathrm{S}, 72^{\circ} 51^{\prime} \mathrm{W}$

WIF $7 \quad 53^{\circ} 19^{\prime} \mathrm{S}, 72^{\circ} 51^{\prime} \mathrm{W}$

WIF $8 \quad 53^{\circ} 18^{\prime} \mathrm{S}, 72^{\circ} 52^{\prime} \mathrm{W}$

WIF $9 \quad 53^{\circ} 18^{\prime} \mathrm{S}, 72^{\circ} 53^{\prime} \mathrm{W}$

WIF $1053^{\circ} 18^{\prime} \mathrm{S}, 72^{\circ} 54^{\prime} \mathrm{W}$

WIF $1153^{\circ} 17^{\prime} \mathrm{S}, 72^{\circ} 56^{\prime} \mathrm{W}$

WIF $1253^{\circ} 16^{\prime} \mathrm{S}, 72^{\circ} 56^{\prime} \mathrm{W}$

WIF $1353^{\circ} 16^{\prime} \mathrm{S}, 72^{\circ} 55^{\prime} \mathrm{W}$

WIF $14 \quad 53^{\circ} 17^{\prime} \mathrm{S}, 72^{\circ} 54^{\prime} \mathrm{W}$

Wyndham glaciers

WG1 $53^{\circ} 17^{\prime} \mathrm{S}, 72^{\circ} 57^{\prime} \mathrm{W}$

WG2 $53^{\circ} 16^{\prime} \mathrm{S}, 72^{\circ} 57^{\prime} \mathrm{W}$

WG3 $53^{\circ} 16^{\prime} \mathrm{S}, 72^{\circ} 50^{\prime} \mathrm{W}$

Torres icefield

TIF1 $53^{\circ} 15^{\prime} \mathrm{S}, 72^{\circ} 48^{\prime} \mathrm{W}$

TIF2 $53^{\circ} 16^{\prime} \mathrm{S}, 72^{\circ} 48^{\prime} \mathrm{W}$

TIF3 $53^{\circ} 15^{\prime} \mathrm{S}, 72^{\circ} 49^{\prime} \mathrm{W}$

TIF4 $53^{\circ} 15^{\prime} \mathrm{S}, 72^{\circ} 49^{\prime} \mathrm{W}$

TIF5 $53^{\circ} 15^{\prime} \mathrm{S}, 72^{\circ} 49^{\prime} \mathrm{W}$

$\begin{array}{rrccrrr}2.2 & 1.9 & \mathrm{~N} & \mathrm{~N} & 900 & 500 & 400 \\ 1.7 & 2.3 & \mathrm{~N} & \mathrm{~N} & 905 & 300 & 605 \\ 1.5 & 0.4 & \mathrm{~N} & \mathrm{~N} & 905 & 700 & 205 \\ 2.7 & 1.4 & \mathrm{NE} & \mathrm{N} & 905 & 400 & 505 \\ 1.6 & 0.8 & \mathrm{~S} & \mathrm{~N} & 905 & 600 & 305 \\ 1.4 & 0.5 & \mathrm{SE} & \mathrm{N} & 905 & 640 & 265 \\ 3.2 & 1.4 & \mathrm{SE} & \mathrm{L} & 800 & 350 & 550 \\ 1.1 & 0.8 & \mathrm{E} & \mathrm{N} & 900 & 420 & 480 \\ 1.4 & 0.7 & \mathrm{~S} & \mathrm{~N} & 900 & 500 & 400 \\ 1.7 & 2.2 & \mathrm{~S} & \mathrm{~N} & 800 & 400 & 400 \\ 1.8 & 1.0 & \mathrm{~S} & \mathrm{~N} & 828 & 550 & 278 \\ 0.4 & 0.1 & \mathrm{~N} & \mathrm{~N} & 750 & 700 & 50 \\ 1.4 & 0.6 & \mathrm{~N} & \mathrm{~N} & 700 & 500 & 200 \\ 2.4 & 1.3 & \mathrm{~N} & \mathrm{~N} & 800 & 400 & 400 \\ & \mathbf{1 5 . 4} & & & & & \end{array}$

$\begin{array}{lllllll}2.2 & 1.3 & \mathrm{~S} & \mathrm{~N} & 1124 & 420 & 704\end{array}$ $\begin{array}{lllllll}0.7 & 0.3 & \text { NW } & \text { N } & 1124 & 700 & 424\end{array}$ $\begin{array}{lllllll}1.8 & 0.6 & \text { SE } & \text { N } & 500 & 400 & 100\end{array}$ $\begin{array}{lllllll}1.4 & 0.7 & \mathrm{~N} & \mathrm{~N} & 970 & 600 & 370\end{array}$ $\begin{array}{lllllll}0.8 & 0.2 & \text { SE } & \text { N } & 500 & 400 & 100\end{array}$

3.1

3.1
0.5
4.9
2.6
3.6
2.8
3.5
2.7
3.4
2.3
0.9
2.2
4.3
2.1

$\begin{array}{llllll}1.8 & \mathrm{~N} & \mathrm{~N} & 1000 & 400 & 600\end{array}$ $\begin{array}{llllll}0.2 & \mathrm{~N} & \mathrm{~N} & 700 & 500 & 200\end{array}$ $\begin{array}{llllll}5.8 & \mathrm{~N} & \mathrm{~L} & 1152 & 300 & 852\end{array}$ $\begin{array}{llllll}3.2 & \mathrm{~N} & \mathrm{~N} & 1183 & 400 & 783\end{array}$ $\begin{array}{llllll}5.2 & \mathrm{E} & \mathrm{N} & 1000 & 700 & 300\end{array}$ $\begin{array}{llllll}1.7 & \text { SE } & \text { N } & 1000 & 100 & 900\end{array}$ $\begin{array}{llllll}3.0 & \text { S } & \text { L } & 1000 & 100 & 900\end{array}$ $\begin{array}{llllll}2.6 & \text { SW } & \mathrm{N} & 1183 & 800 & 383\end{array}$ $\begin{array}{llllll}2.3 & \text { SW } & \mathrm{N} & 1152 & 500 & 652\end{array}$ $\begin{array}{llllll}0.1 & \text { NW } & \mathrm{N} & 1000 & 600 & 400\end{array}$ $\begin{array}{llllll}0.6 & \mathrm{~S} & \mathrm{~N} & 973 & 400 & 573\end{array}$ $\begin{array}{llllll}1.6 & \mathrm{~N} & \mathrm{~N} & 973 & 500 & 473\end{array}$ $\begin{array}{llllll}27 & \mathrm{~N} & \mathrm{~N} & 900 & 500 & 400\end{array}$ $\begin{array}{llllll}1.2 & \mathrm{~N} & \mathrm{~N} & 900 & 500 & 400\end{array}$ 32.0

$\begin{array}{lllllll}0.5 & 0.1 & \mathrm{~N} & \mathrm{~N} & 800 & 650 & 250\end{array}$ $\begin{array}{lllllll}0.5 & 0.1 & \mathrm{~N} & \mathrm{~N} & 973 & 850 & 123\end{array}$ $\begin{array}{lllllll}1.1 & 0.4 & \mathrm{~N} & \mathrm{~N} & 874 & 520 & 354\end{array}$ 0.6

$\begin{array}{lllllll}1.7 & 1.6 & \mathrm{NE} & \mathrm{N} & 720 & 500 & 220\end{array}$ $\begin{array}{lllllll}1.1 & 0.3 & \text { SE } & \text { N } & 800 & 500 & 300\end{array}$ $\begin{array}{lllllll}1.0 & 0.5 & \mathrm{~S} & \mathrm{~N} & 800 & 500 & 300\end{array}$ $\begin{array}{lllllll}1.3 & 0.6 & \mathrm{~S} & \mathrm{~N} & 800 & 600 & 200\end{array}$ $\begin{array}{llllllll}1.0 & 0.8 & \mathrm{~N} & \mathrm{~N} & 750 & 500 & 250\end{array}$

Torres glacier

TG $\quad 53^{\circ} 16^{\prime} \mathrm{S}, 72^{\circ} 47^{\prime} \mathrm{W}$

Perez glacier

PG $\quad 53^{\circ} 22^{\prime} \mathrm{S}, 72^{\circ} 39^{\prime} \mathrm{W}$

$\mathrm{N}$

N 948400548

Henry glacier

$\begin{array}{lllllllll}\text { HG } & 53^{\circ} 25^{\prime} \mathrm{S}, 72^{\circ} 40^{\prime} \mathrm{W} & 0.66 & 0.1 & \text { SW } & \text { N } & 700 & 600 & 100\end{array}$

Piedras glacier

$\begin{array}{lllllllll}\text { PG } & 53^{\circ} 10^{\prime} \mathrm{S}, 72^{\circ} 40^{\prime} \mathrm{W} & 0.95 & 0.9 & \mathrm{E} & \mathrm{N} & 802 & 470 & 332\end{array}$

TOTAL
Table 2. Estimated glacier areas for isla Riesco

Polygon name Polygon No. $\quad A_{\mathrm{L}} \quad R \quad R^{*}$ Glacier area $\mathrm{km}^{2} \quad \mathrm{~km}^{2}$

Córdova icefield and glaciers

$\begin{array}{rrrrr}10 & 38.1 & 0.56 & 0.56 & 21.3 \\ 11 & 54.2 & 0.68 & 0.63 & 34.0 \\ 12 & 6.5 & 0.32 & 0.32 & 2.1 \\ 13 & 17.7 & 0.40 & 0.40 & 7.2 \\ 14 & 20.8 & 0.43 & 0.43 & 8.9 \\ 15 & 134.3 & 1.29 & 0.63 & 84.3 \\ 16 & 48.9 & 0.63 & 0.63 & 31.3 \\ 17 & 37.4 & 0.55 & 0.55 & 20.7 \\ 18 & 9.9 & 0.34 & 0.34 & 3.4 \\ 19 & 5.2 & 0.31 & 0.31 & 1.6 \\ & \mathbf{3 7 3 . 0} & & & \mathbf{2 1 4 . 8}\end{array}$

Wyndham icefield and glaciers

Notes: Polygon No. refers to a group of polygons of glacier areas interpreted from the Landsat image. For península Córdova, polygon names have been added for Córdova, Wyndham and Torres icefields and glaciers. The smaller glaciers in península Córdova (Perez, Henry and Piedras) are not included since they could not be detected on the Landsat image. Polygon numbers $\geq 13$ are located on isla Riesco outside of península Córdova. $A_{\mathrm{L}}$ is the glacier area interpreted using the Landsat image. $R$ is the ratio of area determined by aerial photos $\left(A_{\mathrm{P}}\right)$, divided by the area determined by Landsat imagery $\left(A_{\mathrm{L}}\right)$, according to the linear regression of Figure 3. $R^{*}$ is the corrected ratio adopted for estimating glacier areas. Where $A_{\mathrm{L}} \geq 48.9 \mathrm{~km}^{2}$, a constant ratio $R^{*}=0.63$ was adopted (see text).

to avoid obtaining unrealistically large values of $R$. In fact, glacier areas of $>47 \mathrm{~km}^{2}$ on the Landsat image are also largely covered by fresh snow, thus overestimating the real glacier extension.

a.

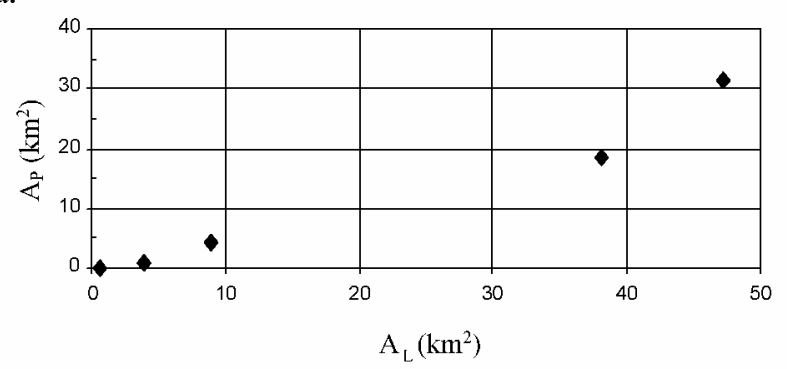

b.

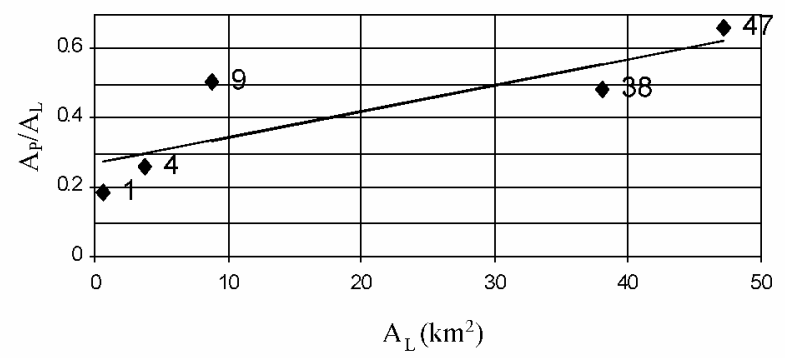

Fig. 4. (a) Plot of glacier areas interpreted from a supervised classification of the 6 October 1986 Landsat image $\left(A_{\mathrm{L}}: x\right.$ axis) vs the area interpreted from aerial photographs of 1984 ( $A_{\mathrm{P}}:$ y axis). (b) Plot of $A_{\mathrm{L}}$ (x axis) vs ratio of $A_{\mathrm{P}} A_{\mathrm{L}}{ }^{-1}$ (y axis). Numbers attached to data points represent areas obtained from the Landsat image, in $\mathrm{km}^{2}\left(A_{\mathrm{L}}\right)$. Data points correspond to the following glaciers: 1. Perez glacier; 4. Piedras and Henry glaciers; 9. Torres icefield and Torres glacier; 38. Córdova icefield and CG1-CG5; 47. Wyndham icefield and WG1-WG3. The line represents a best linear fit with $y=$ $0.0076 x+0.269$, and $r=0.84$, valid for $1 \leq A_{\mathrm{L}} \leq 47 \mathrm{~km}^{2}$. For $A_{\mathrm{L}}>47 \mathrm{~km}^{2}$ a constant value of $A_{\mathrm{P}} / A_{\mathrm{L}}=0.63$ is assumed ( see text). 
The total glacier area for the rest of isla Riesco, corresponding to polygons $13-19$ in Table 2, is $157 \pm 40 \mathrm{~km}^{2}$. Adding this area to the glacier-covered area of península Córdova obtained by aerial photographs $\left(56.8 \mathrm{~km}^{2}\right)$ yields a total glacier area of $215 \pm 40 \mathrm{~km}^{2}$ for isla Riesco, neglecting errors in the area calculation using the aerial photos. The value of $215 \mathrm{~km}^{2}$ is more than double the previous estimate of $100 \mathrm{~km}^{2}$ (Casassa, 1995), which was calculated based on 1:250000 maps. This shows the need for an improved inventory based on new observations. Considering the high cost of acquiring dedicated aerial photographs, particularly suitable is satellite coverage obtained in a more convenient season (minimized fresh snow cover) with unsaturated pixels over snow and ice and increased resolution compared to Landsat TM. Landsat 7 and the Advanced Spaceborne Thermal Emission and Reflection Radiometer (ASTER) offer possibilities for such coverage.

\section{GLACIER VARIATIONS AND SENSITIVITY TO REGIONAL GLIMATIC CHANGE}

No field data exist for the ELA on isla Riesco. Likewise, the ELA could not be estimated based on 1984 aerial photography or using the 1986 Landsat image, because of image saturation and lack of contrast between snow and ice. Although glaciers show some signs of retreat (see below), it is reasonable to estimate that they have a meaningful accumulation area to replenish at least part of the ablated ice. Therefore, the equilibrium line should be located below $900 \mathrm{~m}$, where nearly all glaciers are located, but above $500 \mathrm{~m}$, the average elevation of glacier fronts, which are located on relatively steep mountain slopes. Any changes in ELA should affect small areas of the glaciers, so the glaciers of isla Riesco should be rather insensitive to climate change (Furbish and Andrews, 1984; Tangborn and others, 1990).

The presence of trimlines above present ice surfaces, and moraines beyond the present position of the glaciers as observed on aerial photographs, indicates that the glaciers of isla Riesco are in a general state of retreat from a Holocene neoglacial, as is evident in other glaciers of southern South America (Clapperton, 1993; Aniya and others, 1997; Rivera and others, 2002). The glacier retreat can probably be correlated with the regional warming of $1.3-2.0^{\circ} \mathrm{C}$ (100 years $)^{-1}$ observed in Chile during the last 60 years (Rosenblüth and others, 1995), a trend which is also observed in Argentine Patagonia (Ibarzabal and others, 1996). Another factor which should contribute to glacier recession is the precipitation decrease of $25-33 \%$ detected at faro Evangelista and bahía Félix stations during the periods 1899-1988 and 1915-85, respectively (Rosenblüth and others, 1995). In the last 15 years, however, a few regional stations show a precipitation increase, as well as an apparent reduction in climate warming (personal communication from J. Carrasco, 2000]), which may result in a future glacier stabilization or readvance.

\section{GONGLUSIONS}

Analyses of aerial photographs acquired during mid- and late summer, in combination with 1:100000 topographic maps, proved adequate for compiling a glacier inventory for península Córdova, isla Riesco. The inventory was extended to all of the western part of isla Riesco using a Landsat TM image acquired in early spring, which shows abundant snow coverage, including glacier-free areas. Although the image does not clearly distinguish between seasonal snow areas and glacier areas, a supervised classification method, in combination with an on-screen image interpretation scheme, was adjusted for the glacier area of península Córdova and allowed to extrapolate the glacier inventory for all the western part of isla Riesco, yielding an approximate total glacier area of $215 \pm 40 \mathrm{~km}^{2}$ for the island.

\section{ACKNOWLEDGEMENTS}

Part of this work was funded by project FONDECYT 1980293 and by an internal project of Universidad de Magallanes. Centro de Estudios Científicos is a Millennium Science Institute. Aerial photographs were kindly loaned by Empresa Nacional del Petróleo, Punta Arenas, Chile. C. Acuña provided valuable assistance with digital cartography and photo interpretation at Departamento de Geografía, Universidad de Chile. A student scholarship from the Technical University of Denmark funded the stay of $\mathrm{K}$. Smith in Punta Arenas. R. Kilian kindly provided access to the Landsat image.

\section{REFERENGES}

Aniya, M. 1988. Glacier inventory for the Northern Patagonia Icefield, Chile, and variations 1944/45 to 1985/86. Arct. Alp. Res., 20(2), 179-187.

Aniya, M., H. Sato, R. Naruse, P. Skvarca and G. Casassa. 1996. The use of satellite and airborne imagery to inventory outlet glaciers of the Southern Patagonia Icefield, South America. Photogramm. Eng. Remote Sensing, 62(12), 1361-1369.

Aniya, M., H. Sato, R. Naruse, P. Skvarca and G. Casassa. 1997. Recent glacier variations in the Southern Patagonia Icefield, South America. Arct. Alp. Res., 29(1), 1-12.

Casassa, G. 1995. Glacier inventory in Chile: current status and recent glacier variations. Ann. Glaciol., 21, 317-322.

Casassa, G., L. E. Espizúa, B. Francou, P. Ribstein, A. Ames and J. Alean 1998. Glaciers in South America. In Haeberli, W., M. Hoelzle and S. Suter, eds. Into the second century of worldwide glacier monitoring: prospects and strategies. Paris, UNESCO Publishing, 125-146. (Studies and Reports in Hydrology 56.)

Clapperton, C. M. 1993. Quaternary geology and geomorphology of South America. Amsterdam, Elsevier.

Dirección General de Aguas. 1987. Balance hidrico de Chile. Santiago, Ministerio de Obras Públicas.

Engman, E.T. and R. J. Gurney. 1991. Remote sensing in hydrology. London, Chapman and Hall.

Furbish, D. J. and J. T. Andrews. 1984. The use of hypsometry to indicate long-term stability and response of valley glaciers to changes in mass transfer. 7. Glaciol., 30(105), 199-211.

Holmlund, P. and H. Fuenzalida. 1995. Anomalous glacier responses to 20th century climatic changes in Darwin Cordillera, southern Chile. F. Glaciol., 41(139), 465-473

Ibarzabal y Donángelo, T., J. A. J. Hoffmann and R. Naruse. 1996. Recent climate changes in southern Patagonia. Bull. Glacier Res. 14, 29-36.

Kilian, R., H. Biester, J. Müller, K. Eusterhues, G. Casassa and C. Schneider. 2000. Climatic and volcanic influences on the Late Pleistocene and Holocene lacustrine sedimentation in the southernmost Andes $\left(53^{\circ} \mathrm{S}\right)$. In IX Congresso Geológico Chileno, 31 Fuly-4 August 2000, Puerto Varas, Chile. Proceedings. Vol. 2. Santiago, Sociedad Geológica de Chile, 35-39.

Rivera, A., G. Casassa, C. Acuña and H. Lange. 2000. Variaciones recientes de glaciares en Chile. Rev. Invest. Geogr., 34, 29-60.

Rivera, A., C. Acuña, G. Casassa and F. Brown. 2002. Use of remotely sensing and field data to estimate the contribution of Chilean glaciers to eustatic sea-level rise. Ann. Glaciol., 34 (see paper in this volume).

Rosenblüth, B., G. Casassa and H. Fuenzalida. 1995. Recent climatic changes in western Patagonia. Bull. Glacier Res. 13, 127-132.

Tangborn, W.V., A. G. Fountain and W. G. Sikonia. 1990. Effect of area distribution with altitude on glacier mass balance - a comparison on North and South Klawatti glaciers, Washington State, U.S.A. Ann. Glaciol., 14, 278-282. 